\title{
The Tax Communication Strategy for Urban Society: Survey on Individual Tax Compliance in Indonesia
}

\author{
Agustine Dwianika ${ }^{1}$, Naurissa Biasini ${ }^{2}$ \\ \{ agustine.dwianika@upj.ac.id ${ }^{1}$; naurissa.biasini@@upj.ac.id² $\}$ \\ Universitas Pembangunan Jaya, Jl. Cendrawasih Raya Blok B7/P, Sawah Baru, Ciputat, \\ Kota Tangerang Selatan, Banten.
}

\begin{abstract}
Tax Communication Environment and Tax Communicator Competency are very important to gain the Tax Compliance, hence tax communication would be considered a success . This study was conducted in Urban Society in Indonesia such as Jakarta, Bogor, Depok, Tangerang and Bekasi. The purpose of this study is to find new measurement model to improve the tax compliance of urban society. Research instrument used in the form of questionnaire, that distributed to a hundred fifty respondents. The findings of this study show that: (1) the direct effect of communication enviroment on individual tax compliance is positive and significant. (2) the direct effect of communicator compentency on individual compliance is insignificant. This study contributes not only to the research literature but also to help tax institution to develop strategies toward improving tax compliance. Especially on tax communication approach in urban society.
\end{abstract}

Keywords: Tax Communication, Tax Environtment, Tax Competency, Urban Society and Linier Regression.

\section{Introduction}

Tax compliance continues to be a continuous discussion at the global level until now, especially in times of recession due to the Covid-19 pandemic that has hit almost all countries in the world. Tax revenue is one of the key revenues for implementing the government agenda, but there are still many challenging problems in terms of certainty of tax revenues.

From an economic perspective, taxes have a very strategic value. It means the transfer of individual citizen resources to the wider community sector. This research is needed to determine the strategy for increasing tax compliance in the communication aspect.

This study aims to provide empirical evidence on the relationship between communication's environment and communicator competency as an important part of the tax communication strategy to improve tax compliance. Previous large-scale studies found that taxpayers' attitudes and behavior changed when having discussions with others. At present, there is also a lot of discussion about tax communication ties. The influence and use of social norms has become a separate focus in efforts to improve tax compliance. Likewise, the use of social networks and persuasive messages in tax compliance campaigns [7], [16], [21]. In Bandung, Indonesia, there is a communication strategy that prioritizes restaurant tax rewards which are published in Tax Magazine by KPP [15]. 
This research is needed to determine the strategy for increasing tax compliance in the communication aspect. The importance of tax communication strategy research in fiscal policy which can affect tax compliance needs further investigation. Environmental factors and communicator competency are at the core of efforts to optimize the tax communication strategy. This environmental factor really depends on the government's goal of getting taxes. Almost all taxes produce distortions in the economy of a country and affect the behavior of its citizens. In fact governments often legislate in order to influence individuals' behavior, for instance by offering tax incentives to home buyers to encourage home ownership [8]. In this case the tax authorities will strive for a supportive tax environment so that tax compliance occurs. In Indonesia, tax ratio is one of serious goverment consideration. Indonesia's tax ratio (2014) compared with other countries based on income level are summarized in Figure 1.

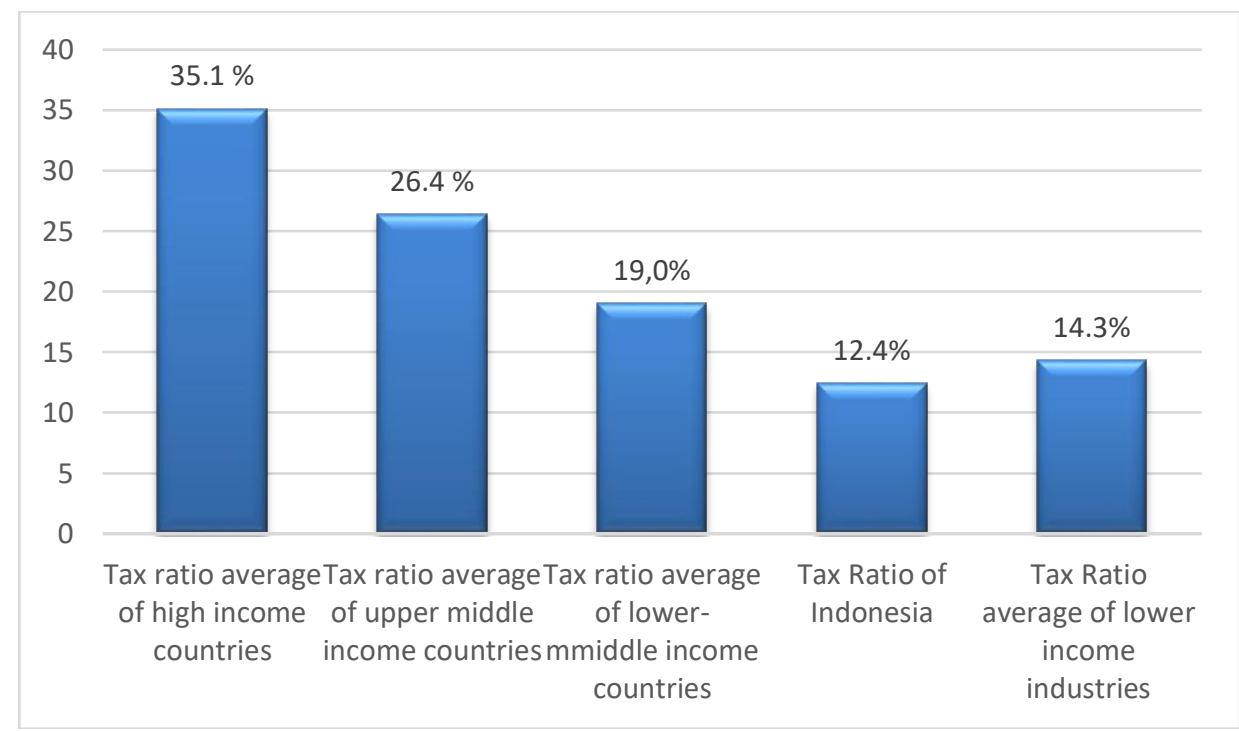

Fig. 1. Indonesia's Tax Ratio Compared With Other Countries Based on Income Level Sources: IMF (2011) \& Indonesia Stated Budget (2014) [10],[13]

To overcome tax compliance problems, it is necessary to prepare a strategy to approach taxpayers appropriately. Among them are the tax communication strategy that puts forward the communication environment factor and communicator competency. This study was conducted in Indonesia, considering that individual tax compliance still needs to be improved. Especially during the recession due to the Covid-19 pandemic. The achievement of the tax ratio is considered to be decreasing, the achievement of the tax ratio clearly has implications for the Indonesian economy [20], so that the tax directorate general needs a strong tax communication strategy, which encourages taxpayers to choose to comply with taxes.

\subsection{Literature Review}

Tax communication cannot be separated from tax compliance. Previous study [6], [18], [21], norms [3], [4], [12] states that the tax administration aspects, tax laws, social norms, individual values and sanctions are closely linked.

Many tax compliance researchers see the view of taxpayer behavior as crucial. This behavior can be influenced by these factors, and many other additional factors. Communication 
between taxpayers plays a role in the perception of social norms on tax avoidance efforts, but also alternative learning about tax laws and their sanctions. For example, someone may feel innocent about tax evasion, because their partner is doing the same thing. They think they are equal. In a similar study, it states that there is a tendency to differentiate taxpayers, but there are similarities in meaning. [5], [11].

In contrast to coworkers, sometimes family discussions have the opposite effect. In fact, it can strengthen one's moral point of view. In social norms, social groups can also influence the perceived risk of catching tax evaders [14]. Knowledge of audits and penalties and perceptions of social norms are two fundamental mechanisms in taxpayer communication.

Experience of paying the same taxes from different cultural backgrounds is a good basis. They can exchange precise information. So that communication within the same job group offers benefits to taxpayers. So that they can be subject to the same regulations and fulfillment of obligations [1], [17].

Tax communication cannot be separated from the social and cultural context of communication. An environment that allows taxpayers to exchange information, so knowing the rules properly also plays an important role. Opportunities for avoiding or wanting to pay the right amount of taxes are an intimate issue [2], [17].

The finding that the process turns out to be a process that can explain why communication with other taxpayers can influence the attitudes of other taxpayers suggests that time spent discussing various kinds of tax issues with their co-workers can reduce tax compliance attitudes. Then they found a way to systematically avoid taxes [17].

Opposing researchers suggest that communication with colleagues who have been audited can trigger tax compliance with Rincke and Traxler (2009)[16]. The development of an appropriate tax communication strategy is a key factor. Therefore, to develope the right tax communication strategy, more attention is needed to the aspects of Communication environment and Communicator competency. Urban communities have an important role in the Indonesian economy, that's why the study of urban communities on the driving factors for tax compliance needs to be studied further. Therefore, the making of the appropriate communication strategy format needs to incorporate these criteria.

\section{Methodology}

The author tries to analyze the data obtained from the results of research and compare it with existing theories, to then be analyzed its application in practice. The purpose of descriptive research is to make description, picture, systematic, factual and accurate facts, traits, and relationships among the various phenomena under investigation [19]. The method that writer use in this research is analytical descriptive method, that is a method in researching status of a group of human being, an object, a condition, a system, and one class of events at present.

To obtain the appropriate data, then this research using research instrument that is in the form of questionnaire. Questionnaires are then distributed to 150 individual tax payer respondents in Jabodetabek with purposive sampling method. The indicator serves as a clue as to whether the variable is working or not. If the indicator is well executed, then it is concluded that the variable is effective, but if the indicator is not executed properly, then the purpose of the variable is not reached. The data analysis in this research will be done by using multiple regression analysis, correlation and coefficient of determination. The variables and indicators and measurement scale used are summarized in Table 2. 
Table 2. Operationalization of Variables

\begin{tabular}{|c|c|c|c|c|}
\hline Variables & Sub-Variables & Indicators & $\begin{array}{c}\text { Indicator- } \\
\text { scale }\end{array}$ & Instrument \\
\hline $\begin{array}{l}\text { Independent } \\
\text { Variable: Tax } \\
\text { Communication } \\
\text { Strategy }\end{array}$ & $\begin{array}{l}\text { X1: } \\
\text { Communication } \\
\text { Enviroment } \\
\text { X2: } \\
\text { Communicator } \\
\text { Compentency }\end{array}$ & $\begin{array}{l}\text { Communication } \\
\text { Enviroment: } \\
\text { - Tax Reporting Room } \\
\text { - Tax Reporting Facilities } \\
\text { - Tax Reporting Locations } \\
\text { Communicator } \\
\text { Compentency: } \\
\text {-Tax communicator's } \\
\text { knowledge } \\
\text { - Tax communicator's soft } \\
\text { skill. }\end{array}$ & Ordinal & Questioner \\
\hline $\begin{array}{l}\text { Variabel } \\
\text { Dependent } \\
\text { Variable: Tax } \\
\text { Compliance (Y) }\end{array}$ & Tax Compliance & $\begin{array}{l}\text { Tax Compliance } \\
\text {-Subjektive Norm } \\
\text {-Understanding of tax law } \\
\text {-Motivation } \\
\text {-Punishment } \\
\text {-Compliance Cost } \\
\text {-Culture }\end{array}$ & Ordinal & Questioner \\
\hline
\end{tabular}

Sources: Prossed Data (2020)

\section{Finding and Discussion}

This study shows the positive results of the implementation of a good tax communication strategy from the tax directorate general to the respondents. As many as $60 \%$ of respondents agreed that communication's environment supports the successful delivery of tax information. And as many as $76 \%$ of respondents agreed that the tax officer had the competence to support the delivery of the required tax information.

The research data has passed the validity and reliability test, with the Cronbach's Alpha value of the tax communication strategy variable of 0.815 or greater than 0.7 . So that it can be said to be reliable. Linear Regression Results show that a good tax communication strategy in the form of good Communication Environment and Communicator's Competency can increase the respondent's decision to comply with taxes. The resulting regression equation is as follows:

$$
\mathrm{Y}=-0.617+0.402 \mathrm{X} 1+0.332 \mathrm{X} 2+\mathrm{e} .
$$

The interpretation of the equation above has a negative constant $(-0.617)$, so it can be said that if there is no tax communication strategy effort, the taxpayer compliance level will decrease. The coefficient value for all independent variables is positive, so if the Communication Environment (X1) and Communicator Competency (X2). This means that if these two aspects 
increase, the level of tax compliance will also increase. So that the more effective the communication that occurs, the better the tax compliance, because overall it has a significant impact.

In supporting operationalization tax collection, the government has issued various tax regulations including laws, regulations government, ministerial decrees, decrees general tax and so on. From various the policy respondent responds with good. This shows an understanding response if the obligation to pay tax is not heeded it will have an impact on sanctions given to him. A conducive tax environment has been created. Ease of access and qualified services continue to be echoed, even starting from internal tax resources. The creation of a taxation environment that indulges these taxpayers is expected to be welcomed by taxpayers. In good faith to obey taxes, not the other way around.

Tax policy is a second issues of the taxpayer environmental factors which plays a role in influencing taxpayer compliance. Policy aspects taxation includes tax sanctions and tax rates. Tax sanctions can be in the form of administrative sanctions in the form of interest, fines, and increases as well criminal sanctions in the field of taxation.

In line with the communication environment, the ability of tax officials to convey information also reflects their competence. Especially in the tax service unit. Respondents considered the tax services provided as long as it is easy, smooth, fast and not convoluted and efficient and economical. Communication is straightforward, flexible and effective. The services provided can improve taxpayer compliance with tax provisions and can reduce cost economy.

This study finds that an adequate tax environment supports to formulate the strategy of good tax communication between taxpayers and tax offices. Also, support from the tax officer's ability to convey the right information with adequate capabilities and a flexible communication style is a key supporting factor for increasing tax compliance. Therefore, tax officers are expected to be able to provide a good tax service atmosphere and be accompanied by good tax knowledge competencies.

\section{Conclusion}

The communication strategy performed by the tax officer has been good, it is seen from the positive respondent's answer to the Communication Environment indicator $(60 \%)$ and Communicator Compentency (76\%). If the tax communication strategy involves both of these, then increased tax compliance can be achieved, which in turn increases tax revenue. This can also be supported by proper socialization which has been proven to increase tax awareness [9]. This study only analyzes the factors of the tax communication strategy in environmental and competency aspects, so it cannot be generalized. Future research can expand studies on the supporting aspects of tax communication strategies such as socialization, tax inclusion or other tax relaxation, especially in relation to the recession phenomenon due to the recent Covid-19 pandemic.

Acknowledgment. We highly appreciate Kemenristek Dikti and LP2M Pembangunan Jaya University for the trust given, as one of the winners in the 2020 Beginner Lecturer Grant program with Contract Number 080 / SP2H / LT / DRPM / 2020, 012 / SP2H / LT-MONO / LL4 / 2020 and 005 / PER-P2M / UPJ-DIKTI / 04.20. Do not forget to the academic community and students of Pembangunan Jaya University who have helped in the process of distributing questionnaires and data. 


\section{References}

[1] J. S. Ashby and P. Webley, "But everyone else is doing it': a closer look at the occupationaltaxpaying culture of one business sector," J. Commun. Appl. Soc. Psychol, vol. 18, no. 3, pp. 194-210, 2008.

[2] J. S. Ashby, P. Webley, and A. S. Haslam, "The role of occupational taxpaying cultures in taxpaying behaviour and attitudes," J. Econ. Psychol., vol. 30, no. 2, pp. 216-227, 2009.

[3] D. D. Bobek, R. W. Roberts, and J. T. Sweeney, "The social norms of tax compliance: Evidence from Australia, Singapore, and the United States," J. Bus. Ethics, vol. 74, no. 1, pp. 49-64, 2007.

[4] K. Boll, "Mapping tax compliance: assemblages, distributed action and practices: a new way of doing tax research," Crit. Perspect. Acc, 2013.

[5] V. A. Braithwaite, Defiance in Taxation and Governance: Resisting and Dismissing Authority in a Democracy. Edward Elgar Publishing, 2009.

[6] R. G. Cummings, J. Martinez-Vazquez, M. McKee, and B. Torgler, "Effects of tax morale on tax compliance: Experimental and survey evidence," 2006.

[7] B. Dincer and C. Dincer, "The effect of tax communication on taxpayers attitude," Int. J. Acad. Res. Bus. Soc. Sci., vol. 8, no. 12, 2018.

[8] P. Hancock, "The tax environment," in Current Issues in Financial Services, London: Macmillan Education UK, 1995, pp. 80-94.

[9] H. Herawati, S. Lusiana, and R. Tambroni, "The Effectiveness of The Sosialization Strategy of Taxation Regulation in Establishing Taxpayer's Objectives in Tax Rights and Obligations," 2017.

[10] International Monetary Fund, "Indonesia: Selected Issues. IMF Country Report No. 11/310,” Org., 2011. [Online]. Available: http://www.imf.org.

[11] E. Kirchler, E. Hoelzl, and I. Wahl, "Enforced versus voluntary tax compliance: The 'slippery slope' framework," J. Econ. Psychol., vol. 29, no. 2, pp. 210-225, 2008.

[12] M. A. McKerchar, Understanding Small Business Taxpayers: Their Sources of Information and Level of Knowledge of Taxation. University of New England, 1995.

[13] Ministry of Finance of Republic Indonesia, "I Account State Budget Realization,"Kemenkeu.go.id, 2014. [Online]. Available: https://www.kemenkeu.go.id/en/publications/old-press-release/i-account-state-budgetrealization-per-june-30-2014/.

[14] E. Ostrom, "Crowding out citizenship," Scan. Polit. Stud., vol. 23, no. 1, pp. 3-16, 2000.

[15] P. B. B, C. A, J. S, and S. G, "Policy Communication Strategy of Restaurant Tax to Increase Bandung's Own-Source Revenue," 2019, vol. 248, p. 012068.

[16] "Deterrence Through Word of Mouth (Working Paper Series of the Max Planck Institute for Research on Collective Goods No2009 04),” Repec.org, 2009. [Online]. Available: http://ideas.repec.org/p/mpg/wpaper/2009.

[17] M. Sigala, C. B. Burgoyne, and P. Webley, "Tax communication and social influence: evidence from a British sample,” J. Community Appl. Soc. Psychol., vol. 9, no. 3, pp. 237-241, 1999.

[18] S. J, B. M, and C. C, "Taxpayer response to an increased probability of audit: evidence from a controlled experiment in Minnesota J," Public. Econ, vol. 79, pp. 455-483, 2001. 
[19] Sugiyono, "The Methods of Quantitative, Qualitative, and R\&D Research"." Kualitatif dan R\&D, Bandung, ALFABETA, 2016.

[20] "Sudah Cukupkah Kepatuhan Pajak Kita?," Pajak.go.id. [Online]. Available: https://www.pajak.go.id/id/artikel/sudah-cukupkah-kepatuhan-pajak-kita.

[21] B. Torgler, "Speaking to theorists and searching for facts: Tax morale and tax compliance in experiments," J. Econ. Surv., vol. 16, no. 5, pp. 657-683, 2002.

[22] B. Torgler, "Tax morale in Latin America," Public Choice, vol. 122, no. 1-2, pp. 133$157,2005$. 